\title{
A Survey for Need Assessment to Classify Learning Styles of Students Studying in Master Degree Programs at Universities
}

\author{
Zafar Iqbal ${ }^{*}$ \\ Zill-e-Huma ${ }^{* *}$ \\ Sana Nasir ${ }^{* * *}$
}

\begin{abstract}
Students' learning is highly subjective owing to their individual differences, environment and background which decide their learning styles. The purpose of this study was to explore learning styles of university students owing to generic role in their learning. There is need to assess whether students of different universities with different backgrounds but with same discipline prefer same or different learning styles. Four general universities were selected; two from each, public sector and privatesector.314 students were involved in the study from selected universities. A questionnaire was developed in the light of literature to explore learning styles of students mainly based on Grasha Reichmann Learning Style Survey (1974). Survey research design was used to collect data. The number of students against every learning style was calculated through statistical distribution. To infer the significance of results, t-test and ANOVA were applied. The findings showed that learning styles were closely linked gender wise. Further, there was no vast difference in learning styles of the students in respect of public and private sector universities. Subject based results are generally aligned but there are variations in couple of subjects like mass communication. The study concludes that students use variety of learning styles in different situations. If teacher used teaching style compatible to preferred students learning style then they would take more interest in the lesson and learn better.
\end{abstract}

Keywords: Learning process, preferred learning styles, university students

\footnotetext{
* Assistant Professor, DNFCE, Allama Iqbal Open University, Islamabad. Zafar.iqbal@aiou.com

${ }^{* *}$ Ex-Graduates, IER, University of the Punjab, Lahore. Zillehuma512@gmail.com

*** Ex-Graduates, IER, University of the Punjab, Lahore. Sananasir939@ gmail.com
} 


\section{Introduction}

Learning is a physical, mental and spiritual activity (Othman \& Amiruddin, 2010) that changes behavior of individuals continuously (Naserieh \& Sarab, 2013). This development occurs differently among individuals due to individual differences. These differences among students produce different learning styles (Othman \& Amiruddin, 2010), which based on intentions and motives of students when facing a learning situation (Diseth, Martin \& Sen, 2003).

Learning styles is the way students understand and process the information efficiently. Students learn more when they perceive knowledge in their preferred learning style (Montogomry, 1995). Even suitability of teaching style directly depends upon the learning style of the students (Naserieh \& Sarab, 2013). When teaching style is compatible with students learning style then there is better provision of learning for students. Learning styles sometimes considered as a strategy because it brings three approaches together including learning strategies, teaching tactics and learning operations (Klement, 2014).

Some students are versatile and change their learning style according to the situation. We all can feel, reflect, think and do but we interpret in different ways, these all factors guide our learning styles (Fatt, 2000). Learning styles represent the main characteristics of a person's identity but changes as the situation change. When students learn from different learning styles their range of learning also increased and they experienced different methods of learning (Phieffer, Holley \& Andrew, 2005).

Students always use the blend of learning styles. Some students use two learning styles at a time, while some students possess the range of 4 to 6 learning styles. It all depends upon the environment they have to experience (Valley, 1997).

Teachers also influence the learning styles of students. It is necessary to be noted that which learning style attracts the attention of student; it will be the learning style of that student (Pashler, McDaniel, Rohrer \& Bjork, 2008). If there is a balance between learning styles and teaching stylesthen willingness to learn will be enhanced. If teacher practices are not aligned with students' learning styles then students showed learning difficulties like boredom, loses focus and show disinterest in courses (Ehrman, 1996). Students also reveal dropout due to mismatch between learning and teaching styles (Felder, 2010).

We should also make sure that curriculum is harmonious to the learning styles of learners. It is essential to know that how students 
access, process and express information in their learning styles (Henderson \& Milton, 2003). Along with curriculum the delivery of content in the class is important for better learning. Students can learn better if teaching practices are designed around the learning styles of the students. It is important that the material should be a blend of concrete information and should have inbuilt lengths to develop higher order skills among students. The content should be fit at all levels regarding coverage of material, age of student, level of learning and their learning styles (Honey \& Mumford, 1992).

The style of students is always associated with individuality but it is also connected with an individual quality, activity and behavior persistent over time (Smith \& Riding, 1999). The situation like time of the day for study and environment like temperature and light also influence the learning of students (Cassidy, 2004).

Roggers (2009) proposed that before being able to discover their learning style, students should aware and understand the psychology of learning. If students develop skills to monitor their own learning they can become more responsible and better learners. The students aware of their learning style are more engaged in learning, with better self-confidence and self-determination. Students need less effort to memorize the content and show high performance when methods of learning changed into the learning styles (Tomuletiu, Pop, Oroian \& Gorea, 2010). Majority of the students are unaware of their learning styles which means their study habits are not based on their preferable learning styles (Honey \& Mumford, 1992). It shows students unaware of their learning style are not able to analyze and identify the place where the improvement is needed (Klement, 2014). As a result, students become bored, inattentive and show poor performance in assessment tests. They get frustrated and start thinking that they cannot do well in this subject anymore and give up their task (Felder \& Henriques, 1995). Owing to this, during teaching a group learning style matched with teaching styles but for some other learner they are not (Dunn \& Dunn, 1999). When a student fails in processing the information at any stage it means there is short fall in their cognitive skills acquisition. Therefore, futile learning will take place (Smith\& Riding, 1999).

Curry (1983) classified the learning styles in a three layered onion model. According to him the outermost layer represented instructional preferences, the middle layer is information processing style and the inner layer consists of cognitive personality. In this research learning styles given by Riechmann and Grasha (1974) are used. Brief description of the learning styles is given in the following paragraphs. As per Grasha 
theory, it includes; competitive, collaborative, participant, dependent, and independent learners.

The competitive learners learn the stuff when they want to perform better than others. They see the classroom as some kind of win-lose situation (Changthong, Manmart \& Vongprasert, 2014). They like to be the center of attention in the class. They want recognition of their accomplishments in the class and take it as a pride (Grasha, 1994). They prefer to be passive and try to absorb more and more by listening to the instructor. They never try to learn in groups but dislike to work with others (Andrews, 1981). They are motivated to learn for the sake of doing better than others (Swanson, 1995).

The student with collaborative learning styles prefers to learn in peers or in social content (Swanson, 1995). The class communication, interaction and collaboration processes enhance peer learning and exhibit team building skills (Moldoven, 2014). They learn in small groups because peer interactions play a key role in such type of learning (Yazici, 2005). They prefer lecture with small group discussions (Grasha, 1994). Collaborative learners not only learn by sharing ideas but helped to share the burden on each individual in the group (Changthong, Manmart \& Vongprasert, 2014).

The participant learners enjoy joining the class and trying to take part in as much activities of the course as possible (Grasha \& Natalia, 2000). They like to interact within a learning environment. They take interaction as an opportunity to interact with others and also to learn the content of course (Swanson, 1995). They prefer to learn from teachers having better ability to analyze and synthesize the information. They also avail all these opportunities which are available regarding learning such as educational conferences, meetings etc. They are highly involved in all course activities (Grasha, 2002).

The students with avoidant learning styles do not show active participation in class thus become uninterested in course content (Swanson, 1995). They try to withdraw from those situations of learning through which they can become frustrated (Andrews, 1981). They do not participate with students and teachers in classroom activities. They overwhelmed by what goes on in the class (Grasha, 1994). They never take the responsibility of their learning that's why they rely on others like in group work they relies on their team members. They prefer no tests. They do not like enthusiastic teachers (Grasha, 1996).

Dependent learners prefer linear style of instruction they feel rewarded if they find attention and guidance. They like structured atmosphere in the classroom (Andrews, 1981). They prefer only those 
assignments which are assessed and set by the teacher (Sadler-Smith, 1996). They become frustrated when they have to address/face new challenges/ situations which were not addressed in the classroom directly (Grasha, 1996). They are stereotype and always oppose innovations or creativity. They prefer to work on define set lines in the class.

Independent learners respond quickly to new learning environments. They are good time managers (Christies, Tett, Cree \& McCune, 2014). They learn content which they think is important for them to learn. They prepare to work alone on course projects. They like to develop their own learning strategies and prefer to structure and restructure their own learning (Rayner \& Riding, 1997). When independent learners ask questions on their own become more satisfied (Andrew, 1981).

The focus of study is to assess and classify the learning styles of students across Grasha's illustrated styles studying in participant universities. Gender-wise difference of learning styles among students will be assessed. Moreover, differences in learning styles of the students studying in public sector and private sector universities will be determined. Subject based learning styles in public sector and private sector universities will also be assessed.

\section{Methodology}

The ontological base of the study is post positivism (Creswell, 2014) for which quantitative research approach is most suitable. Survey research design was used to assess and classify learning styles of the students.

Learning styles were identified through literature. The variation in learning styles of students' effect their learning. According to Riechmann and Grasha, learning styles are independent, dependent, participant, avoidant, competitive and collaborative (1974). It means students can learn by their own, with the help of peers and teachers. They learn through participating in the class by asking questions. They want to learn to be qualified and get understanding of different concepts. Students can learn by competing with other students in the class and collaborating with peers and teachers also. The researchers have taken some steps for execution of study which are given in figure 1. 


\begin{tabular}{|c|c|c|c|c|}
\hline $\begin{array}{l}\text { Identifica- } \\
\text { tion of } \\
\text { learning } \\
\text { styles } \\
\text { through } \\
\text { reviewing } \\
\text { literature }\end{array}$ & $\begin{array}{l}\text { Develop- } \\
\text { ment of } \\
\text { framework } \\
\text { to prepare } \\
\text { Items }\end{array}$ & $\begin{array}{l}\text { Selection } \\
\text { of Public } \\
\text { and Private } \\
\text { sector } \\
\text { general } \\
\text { universities }\end{array}$ & ᄃ) & $\begin{array}{l}\text { Questionn- } \\
\text { aire } \\
\text { Distribution } \\
\text { to the } \\
\text { relevant } \\
\text { students }\end{array}$ \\
\hline
\end{tabular}

Figure 1: Plan and Procedure of the study

\section{Population and Sampling of the Study}

Population of the study was students of master degree programs studying in the universities located in the Punjab Province. These students were belonged to same study programs and had completed their one semester at least in the university. Province of Punjab is considered as the hub of institutions for higher education. Students from different areas of Punjab and from other provinces preceded Lahore city for the sake of education. The students' selection was based on versatility in regions, education and background. All selected universities were general in nature. Moreover, owing to time and resource constraints only universities situated in the capital city of Punjab province were selected in the sample.

It is assumed that all sampled universities are varied in terms of their students' learning styles and teaching strategies. This research study involved 320students, 80 students from each university. The students belonged to same program of study, and almost of same age level. Cluster sampling technique was used to select the participants from selected universities. Four universities were selected in total in which two for each; public sector and private sector. Pseudo names were used for university to hide their identity. Detail of sampled universities is given in figure 2 . 


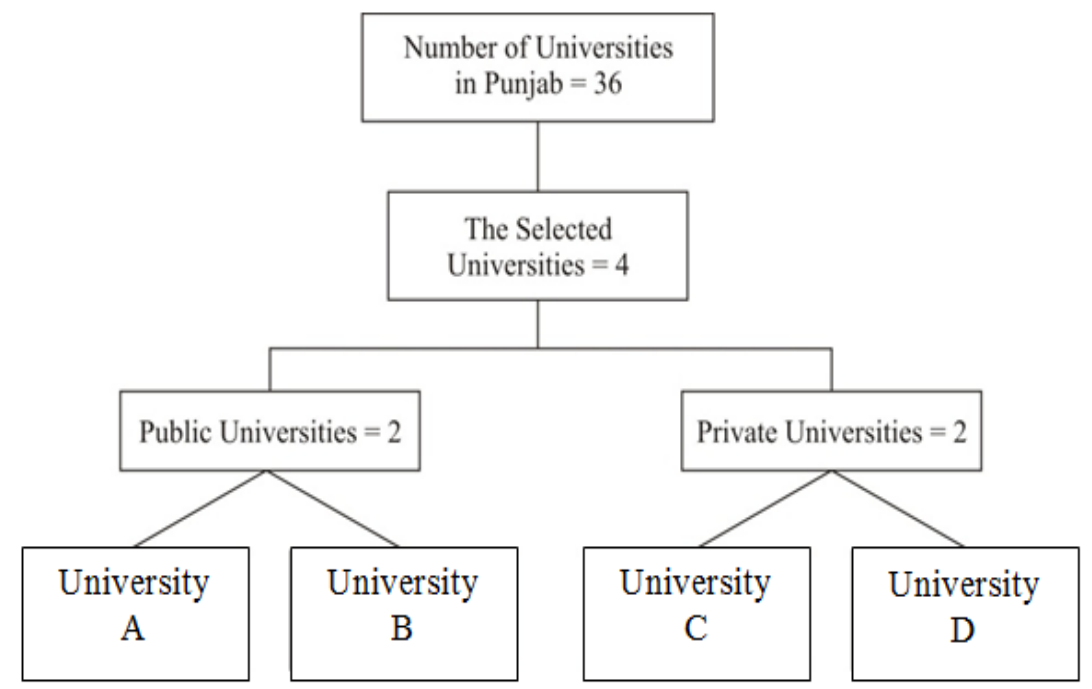

Figure 2: Sample of the study

\section{Development of Research Instrument}

The learning styles of students were identified by reviewing research studies (Grasha, 1994; Kolb \& Kolb, 2005; Honey \& Mumford, 1992). After this it was decided to develop a questionnaire because the instrument of Grasha's did not match with our learning system. We developed an instrument to "classify the learning styles" of university students. It was based on five-point Likert scale ranging from 1(strongly disagree) to 5 (strongly agree).The literature review helped us to draw main ideas and indicators of each learning style to develop an instrument to classify learning styles of the students. The detail of learning styles, scope, number of items against each learning style, an example item and reliability coefficient are given in the following table. 
Table 1

Detail of questionnaire used for assessing Learning Style of University Students

\begin{tabular}{|c|c|c|c|c|c|}
\hline $\begin{array}{l}\mathrm{Sr} \\
\#\end{array}$ & Learning styles & Scope & $\begin{array}{l}\text { No of } \\
\text { Items }\end{array}$ & Example & Reliability \\
\hline 1 & Competitive & $\begin{array}{l}\text { Students who } \\
\text { learn to perform } \\
\text { better than } \\
\text { others }\end{array}$ & 7 & $\begin{array}{l}\quad \text { prefer those } \\
\text { class activities in } \\
\text { which I can } \\
\text { compete } \\
\text { others }\end{array}$ & .60 \\
\hline 2 & Collaborative & $\begin{array}{l}\text { Students who } \\
\text { learn by sharing } \\
\text { ideas and talents }\end{array}$ & 10 & $\begin{array}{l}\text { I prefer to learn } \\
\text { by sharing ideas } \\
\text { with peers }\end{array}$ & .64 \\
\hline 3 & Participant & $\begin{array}{l}\text { Participate with } \\
\text { students and } \\
\text { teachers in class }\end{array}$ & 10 & $\begin{array}{l}\text { I prefer lectures } \\
\text { with discussion }\end{array}$ & .73 \\
\hline 4 & Avoidant & $\begin{array}{l}\text { Typically } \\
\text { uninterested by } \\
\text { what happens in } \\
\text { class }\end{array}$ & 10 & $\begin{array}{l}\text { I am not } \\
\text { enthusiastic } \\
\text { about learning } \\
\text { content }\end{array}$ & .82 \\
\hline 5 & Dependent & $\begin{array}{l}\text { Look to teachers } \\
\text { as a support and } \\
\text { guideline on } \\
\text { what to do }\end{array}$ & 10 & $\begin{array}{lr}\text { I want clear } \\
\text { deadlines and } \\
\text { instructions } \\
\text { assignments }\end{array}$ & .67 \\
\hline 6 & Independent & $\begin{array}{l}\text { Like to work } \\
\text { alone }\end{array}$ & 10 & $\begin{array}{l}\text { I have } \\
\text { confidence in my } \\
\text { learning abilities }\end{array}$ & .73 \\
\hline
\end{tabular}




\section{Piloting of Research Instrument}

The instrument was piloted on 100 students of a university which was not included in the sample. Data we have after piloting, gave us understanding that 10 statements were not giving meaning to respondents or making them confuse. These statements were modified in such a way that respondents may feel ease to read and understand them adequately.

\section{Reliability of Research Instrument}

The Cronbach's alpha of the scale is 0.87 . It represents a very strong reliability of the research instrument. Factor-wise reliability of competitive, collaborative, participant, avoidant, dependent and independent was $0.60,0.60,0.73,0.82,0.67$ and 0.73 respectively.

\section{Administration of Research Instrument and Data Collection}

A survey of selected universities was conducted and research instrument was given to selected students to assess their learning styles. The researchers personally visited universities, went to the classrooms and distributed questionnaires to the students. The respondents were requested to fill up the questionnaire on spot to avoid any problem in this process. The students completed their questionnaires in the presence of researchers.

Three hundred and fifty (350) questionnaires were given to the students while 314 were received back to the researchers because some students were not willing to fill up the questionnaires. There was no bondage on the students to participate in the study. It was totally due to their willingness to participate in the study.

\section{Results and Interpretation}

The analysis of responses of students on six learning styles was calculated through statistical distribution. To infer the significance of results, t-test and ANOVA were applied. The findings drawn from the data analysis are given below. Gender-wise distribution of the sample is given in the figure 3 . 


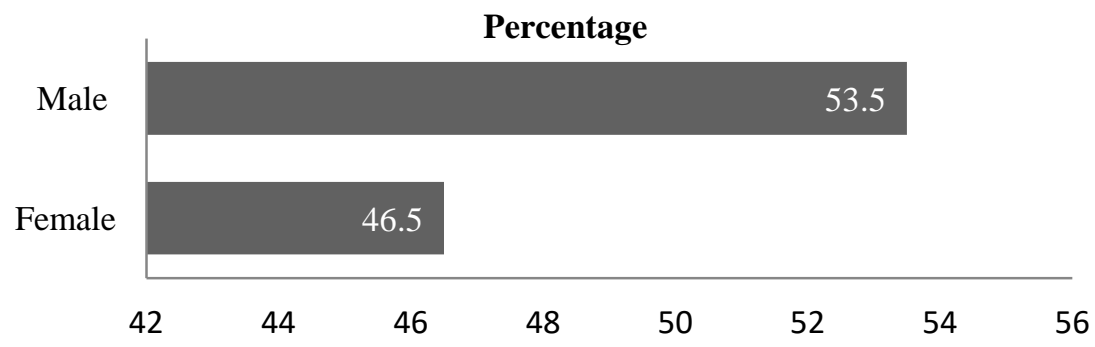

Figure 3: Gender-wise percentage of Participants

Figure 3 shows gender-wise percentage of students participated in the study. Male students' were comparatively large in number $53.5 \%$ to female $46.5 \%$.

Table 2 shows descriptive statistics of learning styles of students of sampled universities. Mainly students at universities learn with collaborative and participative styles. Some are independent learners followed by competitive and dependent learners. Few students avoid contributing and taking part in group work and participate as team member. Main learning style of the university students' is collaborative with mean score 3.73 and least style of students is avoidant with mean score 2.83. In universities, mainly student like to share their thoughts with peers and develop shared understanding.

Table 2

Descriptive statistics of observed learning styles of students

\begin{tabular}{lllll}
\hline Learning Styles & $\mathrm{N}$ & Mean & SD & percentage \\
\hline Competitive & 314 & 3.52 & .72 & 18 \\
Collaborative & 314 & 3.73 & .74 & 18 \\
Participant & 314 & 3.71 & .71 & 17 \\
Avoidant & 314 & 2.83 & .93 & 13 \\
Dependent & 314 & 3.48 & .62 & 17 \\
Independent & 314 & 3.64 & .59 & 17 \\
\hline
\end{tabular}

The percentage of each learning style observed by students of sampled universities is given to see overall contribution of each style. It is evident that in all universities mainly students like to participate (18\%) in sharing based activities and collaborate (18\%) with each other. They are interested to participate in group activities to complete their daily tasks. There are equal percentages (17\%) of students who prefer to be as individual, dependent and independent learners. Least percentage 
(13\%) of students of sampled universities has avoidant learning style. A sufficient percentage of students in universities do not take part in different activities and remain un-participative in the class. Such students are not better learners. They like to be isolated in their daily routine matters and class activities. They avoid to participate in academic task and situations in which shared role is assigned to different students to perform accordingly. They are even reluctant to show their interest in their studies.

Table 3

Gender-wise comparison of students on different learning styles

\begin{tabular}{llllllll}
\hline & & $\mathrm{N}$ & Mean & SD & t-value & Df & p-value \\
\hline Competitive & Female & 146 & 3.43 & .71 & -2.045 & 312 & .042 \\
& Male & 168 & 3.59 & .71 & & & \\
Collaborative & Female & 146 & 3.75 & .79 & .614 & 312 & .539 \\
& Male & 168 & 3.70 & .70 & & & \\
Participant & Female & 146 & 3.69 & .79 & -.454 & 312 & .650 \\
& Male & 168 & 3.73 & .64 & & & \\
Avoidant & Female & 146 & 2.80 & 1.02 & -.589 & 312 & .556 \\
& Male & 168 & 2.86 & .84 & & & \\
Dependent & Female & 146 & 3.49 & .63 & .221 & 312 & .825 \\
& Male & 168 & 3.47 & .62 & & & \\
Independent & Female & 146 & 3.61 & .55 & -.889 & 312 & .375 \\
& Male & 168 & 3.67 & .63 & & & \\
\hline
\end{tabular}

Table 3 shows significant difference in scores of female and male students who like to learn in a competitive environment. It is natural tendency of male students to be more challenging as compare to female students in taking up initiatives. Male students are always interested to maintain their recognition and take it up as a pride. There is no significant difference in male and female students learning styles except competitive learning style. But female students have comparatively more tendency towards group work and further interested to share their thoughts with others as they are mainly dependent in their social role evident from negligible but high mean score in dependent learning style. Male students have comparatively more tendency towards participant, 
avoidant and independent learning styles. Results across the scale of learning styles shows that female students has slightly high mean scores than male students on collaborative and dependent learning styles. While on the other side, male student have comparatively high mean scores in competitive, participant, avoidant and independent learning styles. It is clear that female students are better in collaborative activities and depend on others while male are intended towards independent and individual originated activities.

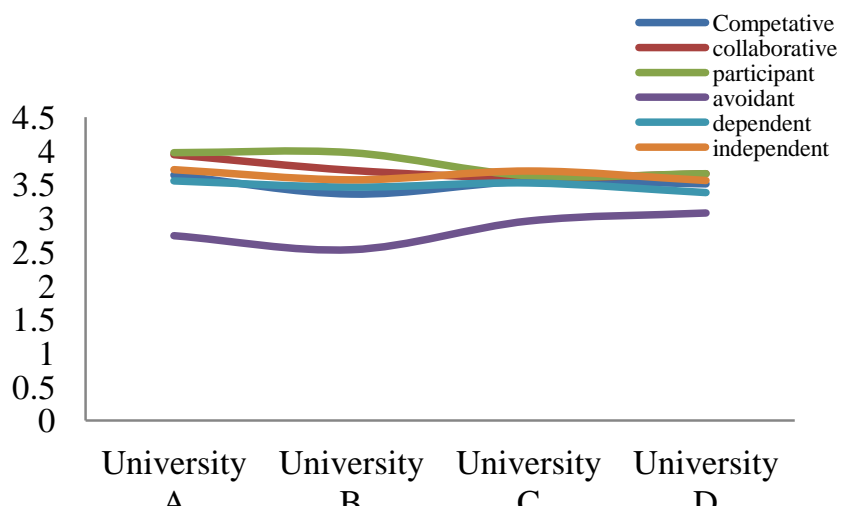

Figure 4: Variations of styles across universities

Figure 4 shows the variations in learning styles being used by the students of participants' universities. The universities were shown on the $\mathrm{x}$-axis while variation in learning styles is showed on the $\mathrm{y}$ - axis. The trend lines against mean scores of different learning styles are drawn to see their degree of variation. Mean score of University-A students is higher in all learning styles except avoidant learning style. The University-B university students have better mean score in collaborative and participant learning styles as compare to private sector universities but equal with University-A in participant but less in collaborative. It is evident from the figure 4that in public sector universities range of learning styles mean score (UniversityA,3.94-2.74;University-B, 3.94-2.53) is higher as compare to private sector universities (University-C, 3.70-2.96; University-D, 3.66-3.08). It can be indicated that students of public sector universities has more specified range of independent learning styles as compare to students of private sector universities. It can be further stated that teacher of public sector universities have clear unified teaching styles which develop and gathered students against specified learning styles of the students. The 
students of private sector universities have more overlapping learning styles of learning as compare to students of public sector universities. Across the universities the students' least learning style is avoidant. It is slight higher in students of University-Athan students of University-Bthen it increases towards University-C and University-D. It means the avoidant learning style is comparatively more intended among University- $\mathrm{C}$ and University-D students.

Table 4

Difference among students' learning styles of participant universities

\begin{tabular}{|c|c|c|c|c|c|c|}
\hline $\begin{array}{l}\text { Learning } \\
\text { Styles }\end{array}$ & Groups & $\begin{array}{l}\text { Sum of } \\
\text { Squares }\end{array}$ & $d f$ & $\begin{array}{l}\text { Mean } \\
\text { Square }\end{array}$ & $\mathrm{F}$ & Sig. \\
\hline Competitive & $\begin{array}{l}\text { Between } \\
\text { groups } \\
\text { Within groups } \\
\text { Total }\end{array}$ & $\begin{array}{l}3.268 \\
159.741 \\
163.009\end{array}$ & $\begin{array}{l}3 \\
310 \\
313\end{array}$ & $\begin{array}{l}1.089 \\
.515\end{array}$ & 2.114 & .098 \\
\hline Collaborative & $\begin{array}{l}\text { Between } \\
\text { groups } \\
\text { Within groups } \\
\text { Total }\end{array}$ & $\begin{array}{l}5.261 \\
168.521 \\
173.782\end{array}$ & $\begin{array}{l}3 \\
310 \\
313\end{array}$ & $\begin{array}{l}1.754 \\
.544\end{array}$ & 3.226 & .023 \\
\hline Participant & $\begin{array}{l}\text { Between } \\
\text { groups } \\
\text { Within groups } \\
\text { Total }\end{array}$ & $\begin{array}{l}7.604 \\
153.676 \\
161.280\end{array}$ & $\begin{array}{l}3 \\
310 \\
313\end{array}$ & $\begin{array}{l}2.535 \\
.496\end{array}$ & 5.113 & .002 \\
\hline Avoidant & $\begin{array}{l}\text { Between } \\
\text { groups } \\
\text { Within groups } \\
\text { Total }\end{array}$ & $\begin{array}{l}14.163 \\
259.128 \\
273.292\end{array}$ & $\begin{array}{l}3 \\
310 \\
313\end{array}$ & $\begin{array}{l}4.721 \\
.836\end{array}$ & 5.648 & .001 \\
\hline Dependent & $\begin{array}{l}\text { Between } \\
\text { groups } \\
\text { Within groups } \\
\text { Total }\end{array}$ & $\begin{array}{l}1.271 \\
120.930 \\
122.200\end{array}$ & $\begin{array}{l}3 \\
310 \\
313\end{array}$ & $\begin{array}{l}.424 \\
.390\end{array}$ & 1.086 & .355 \\
\hline Independent & $\begin{array}{l}\text { Between } \\
\text { groups } \\
\text { Within groups } \\
\text { Total }\end{array}$ & $\begin{array}{l}1.607 \\
109.599 \\
111.207\end{array}$ & $\begin{array}{l}3 \\
310 \\
313\end{array}$ & $\begin{array}{l}.536 \\
.354\end{array}$ & 1.516 & .210 \\
\hline
\end{tabular}

Table 4 does not show significant difference in students who like to learn through competitive learning style and make effort to get incentives as value (.098) is greater than 0.05. The collaborative learning style means the students who prefer group discussion and want to perform every task in group work shows the significant difference across sampled universities because value (.02) is less than 0.05 . The participant learning style in which students learn in small groups shows significant 
difference with value 0.002 . The avoidant learning style, the students who avoid the classes and are satisfied with minimum grades shows the significant difference with value .001 . There is no significant difference in dependent and independent learning styles of students of sampled universities.

Table 5

Comparison of public and private universities acrosstheir students' learning styles

\begin{tabular}{llllllll}
\hline Learning Styles & $\begin{array}{l}\text { Nature of } \\
\text { University }\end{array}$ & $\mathrm{N}$ & Mean & $S D$ & t-value & $d f$ & $\begin{array}{l}\mathrm{p} \text { - } \\
\text { value }\end{array}$ \\
\hline Competitive & $\begin{array}{l}\text { Public } \\
\text { Private }\end{array}$ & 156 & 3.50 & .67 & -.298 & 312 & .766 \\
& & 3.53 & .76 & & & \\
Collaborative & Public & 156 & 3.83 & .66 & 2.37 & 312 & .018 \\
& Private & 158 & 3.63 & .80 & & & \\
Participant & Public & 156 & 3.77 & .64 & 1.55 & 312 & .121 \\
& Private & 158 & 3.65 & .78 & & & \\
Avoidant & Public & 156 & 2.63 & .97 & -3.76 & 312 & .000 \\
& Private & 158 & 3.02 & .85 & & & \\
Dependent & Public & 156 & 3.51 & .62 & .79 & 312 & .429 \\
& Private & 158 & 3.45 & .62 & & & \\
Independent & Public & 156 & 3.65 & .56 & .24 & 312 & .807 \\
& Private & 158 & 3.63 & .63 & & & \\
\hline
\end{tabular}

Table 5 shows that there is no significant difference in most of the learning styles of students studying in public sector or private sector universities. There is significant difference in collaborative learning style and avoidant learning style of the students studying in public sector and private sector universities. The collaborative learning style is used at large by the students studying in public sector universities.

The more focus on collaborative activities shows flexible environment and sharing of Ideas and group activities in public sector universities. The students studying in private sector universities have avoidant style which is significantly different than public sector university students. It can be inferred from this result that private sector university students have more avoidant nature and least contributor in activities as compare to public sector university students. The students with avoidant learning style try to get escape from classes and have high 
absenteeism which shows significant difference in scores of students of public and private sector universities.

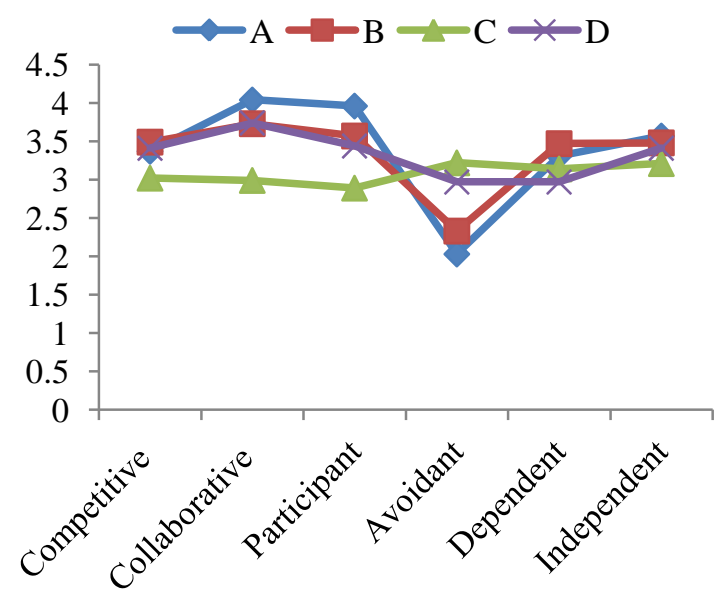

Figure 5: Learning styles of students in subject of Psychology across universities

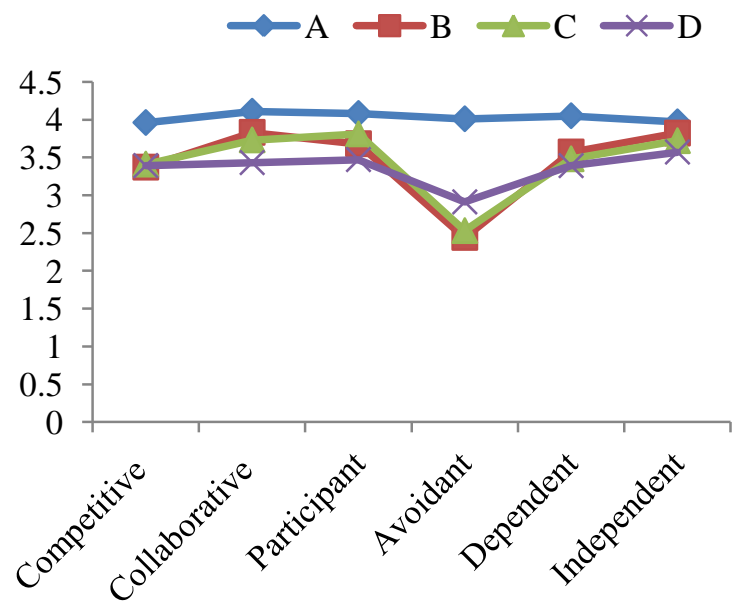

Figure 6: Learning styles of students in subject of English across universities 


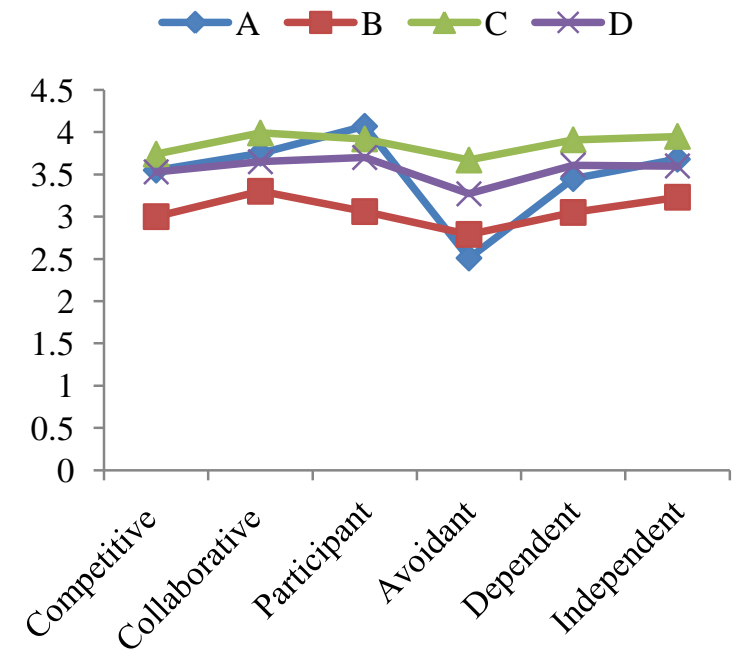

Figure 7: Learning styles of students in subject of Comm. studies across universities

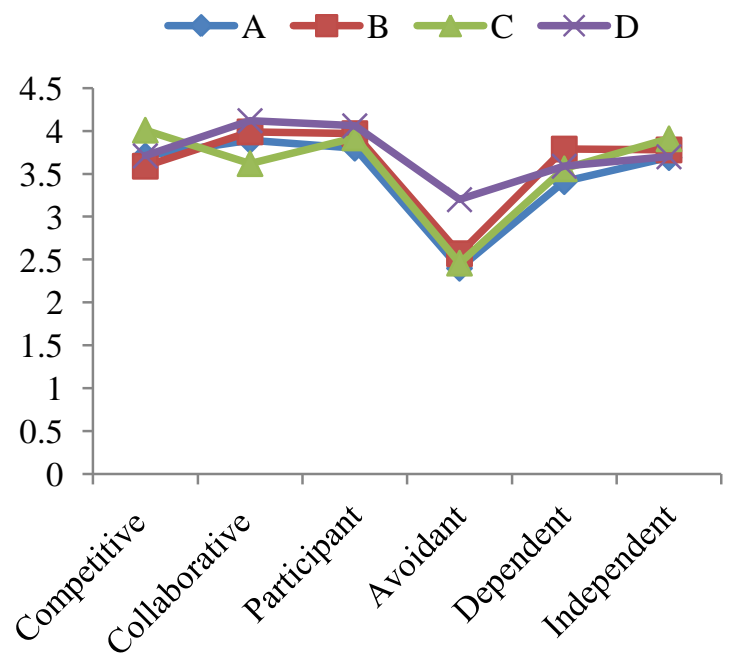

Figure 8: Learning styles of students in subject of Economics across universities 
The students' who are dependent in nature and need a scaffold to initiate a task shows no significant difference in scores for public and private sector universities. The students with independent learning style who need a little support but like to study alone show that there is no significant difference for public and private sector universities. The overall table shows that the scores of public sector universities are better than the private sector universities on the dimensions of collaborative, participant, dependent and independent learning styles. While the remaining dimensions of scale which are competitive and avoidant shows high scores in private sector universities as compare to public sector universities.

Students learning styles of sampled universities in different study program are analyzed and presented in figures 5-8.As mentioned earlier students studying in four programs; Psychology, English, Communication Studies and Economics in sampled universities are included in the study. The results are given in the following section.

Figure 5 shows results of students studying in master degree program of psychology in sampled universities. The students of public sector universities A and B are mainly collaborative and participative in different activities going on in the learning culture. They meagerly avoid the situations but they are independent and dependent learners at reasonable level. The students of university $\mathrm{D}$ of private sector have almost same learning styles like two public sector universities. The students of private sector university $\mathrm{C}$ have slightly different learning styles as compare to other three universities. The private universities students have comparatively more avoidant learning styles. Overall, there is consensus in dependent and independent learning styles of the students in almost across the universities. Except university $\mathrm{C}$ students, others have almost same learning styles studying in the subject of Psychology in different universities.

Figure 6 shows result of students studying in master degree program of English in sampled universities. The learning styles of the students of university $\mathrm{B}$ and $\mathrm{C}$ are almost same. In which university $\mathrm{B}$ is public sector and university $\mathrm{C}$ is private sector. The students of university $\mathrm{A}$ have comparatively high mean scores across the learning styles. While university D students have low mean scores across the learning styles of the students. Except university A students learning styles studying in master degree program of English have almost same styles. Students of three universities B, C and D have equally least learning style which is avoidant. Overall, the numbers of student across the learning styles except A is almost the same. Students of English subject studying in 
different universities are equally competitive, collaborative, participative, independent and dependent learners. They have least number of students with avoidant learning style.

Figure 7 shows leaning styles of the students studying in master degree program of Mass Communication. The styles of the students studying in this program of study in different universities are comparatively more diverse in nature. Public sector university students have mainly collaborative and participative learning styles while avoidant learning style is at least leaning style of students. The subject nature is perhaps more based on sharing of opinions of different individuals among each other. Students studying in private sector universities have almost same level of learning styles from 1-6. The more deviation in learning styles of the students belongs to university A which is a public sector university. Other three university students have least variation in their learning styles. Perhaps the subject is demanding to discuss more and more thus students are mostly have sharing and participating style.

Figure 8 shows leaning styles of the students studying in master degree program of Economics. The students' learning styles are almost at the same level across the scale of learning styles. There is least fluctuation from style to style. Few numbers of students have avoidant learning style across the sampled universities. The number of students has almost equal level of learning styles as compare to other master degree programs. It can be inferred that this subject has very specific nature of contents and teaching demands which closely correlates with the students learning styles as all the university students have close consensus in their learning styles. This commonality is meaningful towards subject requirements and learning demands of the students. They use multiple learning styles in different situations but this evidence is subject oriented.

\section{Discussion}

The study was aimed to classify learning styles of students at post graduate level of four general universities located in Lahore City. Among them, two are from each; public sector and private sector. Public sector universities include the University-A and University-B and from private sector include University-C and University-D. The study assessed variety of learning styles of students studying in these universities. Moreover, gender, university and subject based learning styles were also classified. 
The questionnaire developed to classify learning styles was based on Grasha'stheory originated six learning styles includes competitive, collaborative, participant, avoidant, dependent and independent was used for data collection. The results of the study are important in nature as at university level, it is important to create a match between learning styles and teaching styles to make learning effective. It is also noted that students of university should be aware of their learning styles which may help them in increasing their interest and understanding in the form of better learning. The teachers can have better options to use their teaching styles in the class discussions more compatible and aligned to their students learning styles.

The changes in learning styles develop due to different learning environment, difference in institutions and also due to the difference in male and female intentions towards learning. Male students were better in competitive style as compared to females. Gender wise findings are not significant against learning styles except competitive style. Male students took work as win-lose situation. They were conscious to be better than others and have tendency to work alone. On the other hand, females were likely to be less competitive. They liked to work together. They were slightly more collaborative and dependent as compare to male students. Perhaps their role in the society is mainly sharing and collaborating with others which were reflected through their styles. In our culture, mostly females are dependent on others. Male students were comparatively more independent learners. They take responsibilities for their own studies and decide better for their learning. Male students are comparatively had avoidant learning style in situations. They avoid even to participate in the class or remain less attentive. It can be inferred that male were comparatively less responsible and linger on things due to their laziness. Perhaps, our culture more focus on female initial home based training towards sharing responsibilities while male are considered otherwise. The results with higher mean scores against styles can be linked with their natural tendency as male and female students.

Learning styles are many folded which modifies with teaching styles. Students learning styles comparison across universities is interesting. It would be difficult to generalize results on the basis of small sample size of the study. Level of learning styles in public sector universities is comparatively distinctive in nature. Perhaps it is due to preference given to teaching styles in the classroom or we can say teaching faculty is comparatively better pedagogical knowledge. The private university students mean scores across learning styles are closely related. This reflects that public sector university students learning styles are 
comparatively better matched with teaching styles. The point can be inferred that beyond teaching other factors may cause in developing their learning styles of both sector universities. The students of private sector universities may have comparatively more compatible degree of different learning styles in the classroom with rapid changes in them which reflect the same level of students against learning styles. The private sector students comparatively took less interest in collaborative activities. They are comparatively less organized and often try to remain inattentive or even absent from their classes.

There is significant difference in competitive, collaborative, participant and avoidant learning styles of the students in the sampled universities. It is evident from the results that different university students significantly had different learning styles. The students with dependent and independent leaning styles had no significant difference across the universities. It means that the students depending on others in their studies and independent learners were almost the same whether they belong to public sector or private sector universities. Perhaps the nature of this type of students was closely associated which did not make difference with respect to their type of university or teaching faculty.

The comparison of public and private sector university students is showing significant different in collaborative and avoidant learning styles. In which public sector universities more focus on peer learning process and on social content (Swanson, 1995). They feel that students can learn by sharing ideas and talents (Yazici, 2005). The private sector university students learning style avoidant is significantly difference from public sector universities. Perhaps it is due to leniency in environment and flexible environment of their classrooms. It means that students of these universities enjoy little classroom learning which make them to remain silent and non-productive in their classes. In all remaining four styles of learning there was no significant difference among both type of universities. But the students of public sector universities comparatively prefer participant, dependent and dependent learning styles. It showed clear variety of learning styles being used in public sector universities. The students of private sector universities slightly have more tendencies towards competition. Perhaps it is the matter of their survival and existence for which they race with their competitors available in the market.

Subject wise findings across the universities were very interesting and meaningful. The subject nature and content demands lead students learning styles. The students studying in Psychology and Mass Communication are more flexible in using learning styles to address and 
meet the challenges of their degree programs. These subject's area mainly subjective in nature and focused on individuals' opinions and weightage is given to the personal opinions accordingly. While the students studying in the master degree programs of English and Economics are no more subjective in nature. They are manly objective based on theories and specified rules and content. The students in these subjects have close consensus across the universities irrespective of public or private sector universities. Especially, mass communication students' showed their learning styles spread across 1-6 which is subjective in nature while students studying in the subject of Economics had same learning styles at equal level which was objective in nature. It showed that subject of study leads towards students' style of learning. The alignment between subject matter and students' learning styles irrespective of public or private university students is very meaningful. The subject based trainings, workshops and modules should be developed and arranged for students and faculty to support teaching learning process.

There is need to extend this study by comparing learning styles of students studying in same disciplines of different universities by involving more universities and number of students. Moreover, a study to see compatibility among teachers and students learning styles is also suggested. If teaching style proved as a main drive of students learning style, then teaching strategies can be devised on student centered pedagogies which may help in fulfilling aim of educating our nation. A study is suggested to investigate gender wise learning styles by involving more universities. 


\section{References}

Andrew, J. D. W. (1981). Teaching Format and Student Style Their Interactive Effects on Learning. Research in Higher Education, 16, 18-37.

Cassidy, S. (2004). Learning styles: An overview of theories, models and measures. Journal of Educational Psychology, 24, 419-444.

Changthong, J., Manmart, L., \& Vongprasert, C. (2014). Learning styles: Factors affecting information behavior of Thai youth. Ibres, 24(1), 50-61.

Christie, H., Tett, L., Cree, V. E., \& McCune, V. (2014). It all just clicked: a longitudinal perspective on transitions within University. Studies in Higher Education, 41(3), 478-490.

Creswell, J. W. (2014). Research design qualitative, quantitative, and mixed methods approaches ( $4^{\text {th }} \mathrm{ed}$.). Thousand Oaks, CA: SAGE Publications.

Curry, L. (1983). Learning Styles in Continuing Medical Education. Dttawa: Canadian Medical Association.

Diseth, A., \& Martin, S.O. (2003).Approaches to learning, cognitive style, and as predictors of the academic achievement of the learners. Educational Psychology, 23(2), 195-207.

Dunn,R.,and Dunn, K. (1999).The Complete Guide to the Learning Styles In-service System. Boston, MA: Allyn \& Bacon.

Ehrman, M.E. (1996). Understanding Second Language Learning Difficulties. Thousand Oaks, CA: Sage Publications.

Fatt, J. P. T. (2000). Understanding the learning styles of students: implications for educators, International Journal of Sociology and Social Policy, 20, 31-45.

Felder, R. M. (2010). Are Learning Styles Invalid? (Hint: No!).OnCourse Newsletter, September 27, 2010. A response to claims that no 
evidence justifies taking learning styles into account when designing instruction.

Felder, R., \& Henriques, E. (1995). Learning and teaching styles in foreign and second language education. Foreign Language Annals, $28(1), 21-31$.

Grasha, A. (2002). Teaching with style: a practical guide to enhancing learning by understanding teaching and learning styles. USA: Alliance Publishers.

Grasha, A. F. (1994). A matter of style: The teacher as expert, formal authority, personal model, facilitator and delegator. College Teaching, 42(4), 142-149.

Grasha, A. F. (1996). Teaching with style. Pittsburgh, PA: Alliance.

Grasha, A.F.,\& Natalia, Y. (2000).Integrating teaching styles and learning styles with instructional technology. College Teaching, $48(1), 2-10$.

Henderson, N., \& Milstein, M. M. (2003). Resiliency in schools: Making it happen for students and teachers. Havens of Resilience, 71(1), 2227.

Honey, P., \& Mumford, A. (1986, 1992).The Manual of Learning Styles ( $3^{\text {rd }}$ ed.). Maidenhead: Peter Honey.

Klement, M. (2014). How do my students study? An analysis of students of educational disciplines favorite learning styles according to VARK classification. Social and Behavioral Sciences, 132, 384-390.

Kolb, A. Y., \& Kolb, D. A. (2005). Learning styles and learning spaces: Enhancing experiential learning in higher education. Academy of Management Learning \& Education, 4 (2), 193-212.

Moldovan, L. (2014). iQVET: Innovative Peer Learning Assessment System for Evaluation of trainers and Quality VET professional programs. Retrieved from http://www.histproject.no/sites/histproject .no/files/iQvet_D9_WP5_Validation_final.pdf 
Montgomery, S. M. (1995). Addressing diverse learning styles through the use of multimedia. In: Proceedings of the Frontiers in Education Conference, Vol. 1. IEEE Computer Society, Washington, DC, USA.

Naserieh,F., \& Sarab, M.R.A. (2013).Perceptual learning style preferences among Iranian Graduate students. Systems, 41, 122-133.

Othman, N., \& Amiruddin, M. H. (2010).Different perspectives of learning styles from VARK model. Social and Behavior Sciences,7, 652-660.

Pashler, H., McDaniel, M., Rohrer, D., \& Bjork, R. (2008). Learning styles: Concepts and evidence. Psychological Science in the Public Interest, 9,105-119.

Pheiffer, G., Holley, D., \& Andrew, D. (2005). Developing thoughtful students: using learning styles in an HE context. Education \& Training, 47, 422-431

Rayner, S., \& Riding, R. (1997).Towards a categorization of cognitive styles and learning styles. Educational Psychology, 17, 5-27.

Riechmann, S.W., \& Grasha, A.F. (1974).A Rational Approach to Developing and Assessing the Construct Validity of a Student Learning Style Scales Instrument. The Journal of Psychology, 87, 213-223.

Roggers, K. M. A. (2009). An investigation of and analysis of student learning style preferences in further and higher education. Journal of Further and Higher Education, 33, 13-21.

Sadler-Smith, E. (1996). Learning styles' and instructional design. Innovations in Education and Training International, 33, 185-193.

Smith, E. S.,\& Riding, R. (1999).Cognitive styles and instructional preferences, instructional science, pp.355-371, Netherlands: Kluwer Academic.

Swanson, L.J. (1995). Learning styles: A review of the literature. Educational Research Information Centre document No. ED 387 067. 
Tomuletiu, E.A., Pop, A., Orion, M., \& Gorea, B. (2010). Methodological implications of the diversity of learning styles in higher education practice. Quality Management in Higher Education. Book II, Tulcea: Editor Costache Rusu, 291 - 294.

Valley, K. (1997). Learning styles and courseware design. ALT-Journal, $5(2), 42-51$.

Yazici, H. J. (2005). A study of collaborative learning style and team learning performance. Education and Training, 47 (3), 216 - 229.

\section{Citation of this Article:}

Iqbal, Z., Zill-e-Huma., \& Nasir, S. (2017). A survey for need assessment to classify learning styles of students studying in master degree programs at universities. Pakistan Journal of Education, 34(2), 141-165.

Received on: June $\quad 25,2016$

Revised on: November 28, 2017

Accepted on: December 04, 2017 